\section{Poor countries left behind in rush to claim sea floor}

SIR - The News Feature 'The next land rush' (Nature 451, 12-15; 2008) highlights the challenges faced by states attempting to claim areas of the sea floor under United Nations rules. Although some countries can finance well-resourced expeditions to confront these challenges, the developing world risks being left behind.

Unfortunately, it was not until developing states recently became aware of the extent of potentially eligible seabed territory that their national governments woke up. With the May 2009 submission deadline given by the UN Convention on the Law of the Sea affecting most of them, a different rush has ensued to ensure they are not overlooked in this historical process.

The United Nations is helping many states in Africa, the South Pacific and Latin America to make submissions, but many problems are unresolved as the deadline draws closer.

There are various avenues whereby the world's richer countries could provide muchneeded support to developing states to ensure a fair, strong and complete Article 76 process and guarantee that the poorest states secure their access to deep-marine resources. We call on these countries to increase sharing of marine data and transfer of scientific and technical knowledge. This would be the spark for larger bi- and multilateral cooperation.

Morten Sørensen

UNEP Shelf Programme, Brattekleiv,

4818 Færvik, Norway

\section{Directive will unleash new generation of coal polluters}

SIR - We find that the European Union's proposed directive on carbon-capture 'readiness', as reported in your News story 'Europe to capture carbon', is unacceptable (Nature 451, 232; 2008). It clears the way for a new generation of coal-fired power stations to be built in Europe without any abatement of emissions when they start operating, and without any certainty about when, or if, such technology will be available and affordable.

Already, proposals for new coal plants that will emit tens of millions of tonnes of carbon dioxide are working their way through the planning systems of several European countries. In Britain, for instance, plans for the energy company E.ON's proposed coal power station at Kingsnorth in the Medway estuary, Kent, are with the business secretary, John Hutton, and there's no certainty that he will call a public inquiry to examine the national and international implications.

If allowed, Kingsnorth would start generating in 2012, even before the UK carbon-capture demonstration projects are up and running. With every year that passes without such technology being retrofitted, it would emit more than seven million tonnes of carbon dioxide - ten times more than the entire annual emissions of Rwanda.

If Europe's member states are serious about climate change and meeting the targets they have set themselves for reducing harmful emissions, they will impose strict standards of greenhouse-gas efficiency on all new power stations. New coal-fired power plants of the kind proposed at Kingsnorth should be reconsidered only if carbon capture and sequestration are proved safe, effective and commercially available for fitting from the moment they begin to burn fuel.

Mark Avery ${ }^{\star}$, John Sauvent', Keith Allot;, Benedict Southworths, Andrew Pendleton||

*Royal Society for the Protection of Birds,

The Lodge, Sandy, Bedfordshire SG19 2DL, UK † Greenpeace, Canonbury Villas, London N1 2PN, UK World Development Movement, 66 Offley Road, London SW9 OLS, UK sWWF, Panda House, Weyside Park, Godalming, Surrey GU7 1XR, UK |lChristian Aid, 35 Lower Marsh, London SE1 7RL, UK

\section{How academic corporatism can lead to dictatorship}

SIR - Michael Crow's Book Review of Daniel Greenberg's Science for Sale (Nature 449,$405 ; 2007$ ) calls for a response because it reflects a worsening philosophical divide in US academia between those who regard universities as analogous to corporations and think they should be run that way (mostly career administrators) and those who see universities as primarily intellectual enterprises governed by academic core values (mostly line faculty). Asserting that the university is an idea - not an ideal or an ideology - Crow, who is president of Arizona State University, plays down or ignores most of the dangerous consequences of campus capitalism.

Faculty members would generally hold that universities represent ideals as well as ideas. These are manifest in a value system that is among the first casualties of academic corporatism. Derived from political corporatism, academic corporatism is an administrative strategy that is antithetical to the spirit that academics hold dear including openness, transparency, collegiality, meritocracy, rule-governed procedures, balanced curriculum, a level playing field for probationary faculty and participation by faculty in governance.

Like its political counterpart, academic corporatism often results in dictatorships, with ideas originating only from the top and nothing going the other way. Academic assemblies, unions and senates are eviscerated, neutralized or eliminated altogether. Faculty members are disenfranchised. There is a chilling effect on free speech and the notion of an open marketplace for ideas.

This can wreak havoc with a university's curriculum, jeopardize its intellectual and educational missions and compromise its future. As former Harvard president Derek Bok said: "The end to which this process could lead is not a pleasant prospect to behold." G. A. Clark

Department of Anthropology, School of Human Evolution and Social Change, Arizona State University, Tempe, Arizona 85287-2402, USA

\section{Results of rush to sequence genomes may be nonsense}

SIR - In the Commentary 'Common sense for our genomes' (Nature 449, 783-784; 2007), Steven Brenner welcomes the sequencing of the genomes of James Watson and Craig Venter. Although the generally hypothesis-free collection of large amounts of sequence information may indeed turn out to be important, caution is warranted.

First, it is not the static genome but rather the dynamic proteome that regulates the enormous changes occurring in an organism between conception and death. Second, only the most radical reductionist would argue that a person's essence can be captured by his or her proteome, let alone his or her genome.

Our lives are unrepeatable experiments lacking a control. Myriad external factors interact with genetic and epigenetic factors and with chance to determine whether we are well or ill, smart or dull, successes or failures. A study on some 44,000 twin pairs concluded that environmental and not inherited genetic factors were the main determinants of sporadic cancer (P. Lichtenstein et al. N. Engl. J. Med. 343, 78-85; 2000). Brute-force genome sequencing and Brenner's proposed Genome Commons could yield nonsense if environmental factors are overlooked.

This is not just an academic issue. Membership of the 'diploid genome club' is set to rise rapidly (see Nature 447, 358-359; 2007). The X Prize Foundation is offering the Archon genomics prize of US\$10 million to the first team able to sequence 100 human genomes accurately within ten days. But whether the winners will understand the results is a different question entirely. Thomas C. Erren ${ }^{\star}$, Paul Cullen $\dagger$, Michael Erren $\%$ *Institute and Polyclinic for Occupational and Social Medicine, University of Cologne, D-50937 Köln, Lindenthal, Germany † Medizinisches Versorgungszentrum für Laboratoriumsmedizin Dr Löer, Dr Treder, Hafenweg 11, 49155 Münster, Germany Institute of Clinical Chemistry and Laboratory Medicine, Westphalian Wilhelms-University of Münster, Münster, Germany 